Historic, Archive Document

Do not assume content reflects current scientific knowledge, policies, or practices. 

H. A. ZAGER

Gladiolus Grower

4215 Urbandale Avenue

Des Moines, Iowa
CIARARY

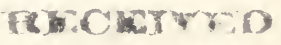

* JAN 311931 .

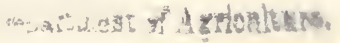

U. S. Department of Agriculture,

WASHINGTON, D. C。

M. R. N.

Bureau of Plant Industry Horticultural Crops and Diseases
$8-3591$ 


\title{
Spring of 1931
}

\section{PRICE LIST OF}

\section{GLADIOLUS BULBS}

Grown by

\section{H. A. Zager}

\author{
Gladiolus Grower \\ 4215 Urbandale Avenue \\ Des Moines, Iowa
}

PLEASE READ BEFORE ORDERING

TERMS: Cash with order or $25 \%$ cash and balance before shipment, or sent C.O.D. for balance due. All quotations prepaid.

No order for less than $\$ 1.00$.

One dozen bulbs of same variety sold at ten times the price of one. Six bulbs for the price of five. Special prices on 100.

I guarantee all bulgs true to name and will gladly replace any free should any errors occur.

L means large size bulbs, $1 \frac{1}{4}$ inches or larger. M, medium size bulbs, $3 / 4$ inch to $1 \frac{1 / 4}{4}$ inch. S, small bulbs $3 / 8$ inch to $\% / 4$ inch.

Name in parenthesis after variety is name of originator. 


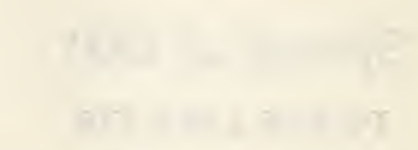

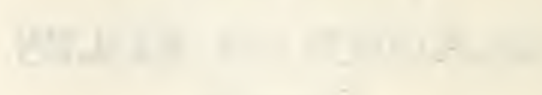


AFLAME. (Hornberger)-Extra large grandiflora Prim. of begonia-rose shading to bright orange flame, 6 or more giant blooms open at once. A fine exhibition variety. (L., each. 25c)

AIDA. (Pfitzer)-Large dark blue purple. Surprisingly early for so large and fine a variety. (M., each 25c)

ALICE TIPLADY. (Kunderd)-Large saffron orange primilinus, one of the best for cut flowers and landscape planting. (M., 6 for 10c) (S., 10c doz.)

ALBANIA. (Kemp)-Large clear white, severai open. The best mid-season white at the price. Good commercial variety. (L., each 5 c) (M., 2 for $5 c$ )

ANNA EBERIUS. (Diener)-Beautiful dark velvety purple, throat amaranth purple, slightly ruffled, very popular, midseason. (M., 5 for 10c)

ANNIE LAURIE. (Brown)-Heavily ruffled delicate pink overlaid with light rose pink, light lavender lines in throat. Very dainty and beautiful; four or five flowers open. A strong grower. (L., each 6c) (M., 3 for 10c) 
ANTHONY ZONKER. (Kunderd)-Extra tall, strong plant, five to seven very large wide open blooms open at one time. Finest deep salmon rose, beautifully placed, lower petals beautifuly blotched. Distinct and showy. (M., each 5c) (S., 5 for $10 \mathrm{c}$ )

BALBOA. (Briggs) - Clear glowing apricot-pink, blending into a warm yellow throat. Four to six open. (L., ea. 8c) (M., 3 for 10c) (S., 6 for 10c)

BARON HULOT. (Lemoine)-Deep indigo blue with fine hair-lines of gold on lower petals, good grower and a standard commercial variety. (L., each 5c) (M., 3 for 10c)

BENGAL TIGER. (Pratt)-Large blossoms of a peculiar shade of smoky red, striped and lined with smoky blue gray; midseason. (L., each $5 \mathrm{c}$ ) (M., 3 for $10 \mathrm{c}$ )

BETTY JOY. (Purple) - Soft creamy white, flushed La France pink. Many open on a fine, strong, straight spike; placement perfect. Medium early. (M., 3 for 10c) (S., 6 for 10c)

BETTY NUTHALL. (Salbach) - Light coral with pale orange throat, feathehred carmine. Tall, magnificent plant and flower. Increases fast. Midseason. (L., each 40c) (M., each 25c)

BLASCO IBANEZ. (Diener)-Self-colored purple, tall slender plant with fine wide open blooms. (M., 2 for 15c) 
BLUE TORCH. (Hornberger)-Lavender blue, similar to Rev. Eubank but a little lighter in color and larger flower, tall straight spike. Several well placed blooms open at a time. Increases well, should make a good commercial variety. (L., each 8c) (M., each 4c) (S., 6 for 10c)

BREAK O' DAY. (Purple)-La France pink on cream, edges deeper pink, good size, robust grower. An early variety (M., 5 for 10c) (S., 10c per doz.)

CAPTAIN BOYNTON. (Boynton)-Large flower on graceful stem, light lavender, deeper color in throat; strong grower and a general favorite. Midseason. (L., each 6c) (M., 2 for $5 \mathrm{c}$ ) (S., 15c per doz.)

CARDINAL PRINCE. (Kunderd) - Clear cardinal red, several open, strong grower. A favorite. (L., each 8c) (M., each 4c) (S., 20c per doz.)

CARMEN SYLVA. (Decorah)-Pure white, faint trace of pink, deep in throat, wiry spike, one of the best white varieties for the price. (L., each 5c) (M., 3 for $5 c$ )

CATHERINA. (Vethuys)-Lavender blue, throat darker with a mahogany red blotch; good substance; flower well placed on spike; very satisfactory; early midseason. (M., 3 for 10c)

CATHERINE COLEMAN. (Coleman)-La France pink shading to geranium pink, with a purple shading in the throat. A very rich shade of pink. Large wide open flowers on tall spikes. A real beauty; late. (L., each 10c) (M., each 5c) 
CHATEAU THIERRY. (Vos)-Orange scarlet with straw yellow blotch in throat, large wide open blooms. (M., 3 for $10 \mathrm{c}$ )

CHERRY RED. (Rockhill)-Glowing cherry red, very early; extra good. (L., each 10c) (S., 2 for $5 c$ )

CORAL. (Rooney)-An early blooming deep coral red, with creamy white throat marking, large blooms and a splendid cut flower variety. (L., each 5c) (M., 2 for 5c)

CRIMSON GLOW. (Betscher)-A favorite large dark crimson, one of the best reds. (M., 2 for $5 \mathrm{c}$ )

CRINKLES. (Kunderd)-Deep peach blossom pink. Intensely ruffled, good grower, increases well. Midseason. (M., 3 for 10c) (S., 6 for 10)

DR. A. C. HANSEN. (Goodrich)-Large flower, distinct form. Shrimp pink blending out to a $\mathrm{La}$ France pink. Tips flowed rose. Very early, blooms in 60 to 65 days. (L., each 5c) (M., 2 for $5 \mathrm{c}$ ) (S., 15c per doz.)

DR. F. E. BENNETT. (Diener)-Vivid orange scarlet; large flower; many open. A fine exhibition variety; strong grower. Best of the scarlet varieties; midseason. (L., each 6c) (M., 3 for 10c) (S., 6 for $15 \mathrm{c}$ ) 
DUCHESS OF YORK. (Dames)-Seedling of Baron Hulot; larger flowers; purple blue; straight stems; vigorous grower; flower well placed with six or more open at once. Early midseason. (M., 3 for 10c) (S., 6 for 10c)

E. J. SHAYLOR. (Kunderd)-Splendid ruffled rose pink; very popular in the cut flower marliets. Fine form and the color is very pleasing. Early midseason. (L., each $5 \mathrm{c}$ ) (M., 2 for $5 \mathrm{c}$ ) (S., 15c per doz.)

EMILE AUBRUN. (Lemoine)-Coppery bronze, overlaid with slate, large cherry red blotch. Very large flowers and many open at a time. Great propagator; an outstanding variety. (M., 2 for $15 \mathrm{c}$ ) (S., 3 for 10c)

EUGENE LEFEDVRE. (Lemoine) - Fine spike, matiy large blooms open, bright rose pink blotshed amaranth purple and cream, originated in France. A fine blotched variety. (L., each 8c) (M., 2 for $5 \mathrm{c}$ ) (S., 15c per doz.)

FERN KYLE. (Kunderd)-Creamy yellow; very: large; wide open highiy ruffled florets. First prize Iowa State Fair, for best cream colored variety. (L., each $6 \mathrm{c}$ )

FLAMING SWORD. (Kelway)-Soft light red. Tall plant with long spike of bloom arranged in single file, hence the name. An early variety. (L., each 5c) (M., 2 for 5c) (S., 15c per doz.) 
FONTAINE. (Coleman) - Beautiful ruffled peaches and cream; one of the best, fine commercial variety, straight spike with well placed florets. (M., 2 for 5c) (S., 4 for 52)

GERALDINE FARRAR. (Diener)-Pale lavender-violet, deep violet spot on lower petals; pronounced light blue cast; very uncommon in glads. Flowers well placed on strong stems. (M., each 8c) (S., 3 for 10c)

GIANT NYMPH. (Coleman) - Light salmon blushed rose, shading to cream in throat; large blooms on good spike; extra good. One of the coming commercial varieties; midseason. (L., each 5c) (M., 5 for 10c) (S., 15c per doz.)

GLORIANA. (Betscher)-Rich salmon, bright and clean color, good straight spike and a good variety in every way. (L., each 8c)

GOLD. (Decorah)-Pure golden yellow; throat a shade deeper; a fine clear yellow, having large florets, perfectly placed and many open at a time; early midseason. (L., each 5c) (M., 2 for 5e) (S., for $5 c$ )

GOID EAGLE. (Austin)-Very prolific and car.y yellow, tall straight spike. (L., each 6c) $\mathrm{N}_{-.}, 3$ for 10c) (S., 6 for $10 \mathrm{c}$ )

GOLDEN DREAM. (Groff)-A pure solid gold yellow without any marking; ; petals recurved in a most attractive shape, strong grower and very tall. Won first prize Iowa Gladiolus Show for best yellow. (L., each 10c) (M., each 5c) (S., 2 for $5 c$ ) 
GOLDEN FRILLS. (Kunderd)-De` $p$ rich daffodil yellow with red lines on lower petals; intensely ruffled, a charming vari $\therefore$ Multiplies rapidly. (L., each 10c) (M., each 5c)

GOLDEN SWALLOW. (Austin)-A beautiful cicar soft yellow with no throat markings; petals are finely ruffled, giving blooms an artistic effect; lovely when massed; early midseason. (L., 3 for 10c) (M., 3 for 5e) (S., 10c per doz.)

HENRY C. GOEHL. (Fischer) - White, slightly fushed pink, large maroon blotch in throat. Very popular. (M., 2 for $5 \mathrm{c}$ ) (S., 10c per doz.)

HERADA. (Austin)-Purest lavender mauve, deeper in throat; immense blooms of glistening lustre, in a class by itself; midseason. (L., each 5c) (M., 5 for 10c) (S., 10c per doz.)

ILLUMINATOR. (Hinkle)-Tall deep rose red, with a bluish tinge, purple lines in throat, several blooms open, stands the dry weather exceptionally well. Early midseason. (L., each 5c) 5c) (IM., 2 for 5c) (S., 15c per doz.)

IWA. (Betscher)-Very tall straight spike; color light rose pink with red blotch. A fine blotched variety; vigor without coarseness. (L., each 5c) (M., 2 for 5c) (S., 15c per doz.) 
J. ELTON CARTER. (Goodrich)-Large coral pink beauty, with rich yellow throat. Winner of Gold Medal Iowa State Fair 1928 for best new variety at the show. Stock very limited. (L., each 50c) (M., each 25c) (S., each 10c)

JANE ADDAMS. (Decorah) - Very large lavender, wide open blooms shading to lighter throat, extra good variety. (M., each 15c) (S., 2 for 15c)

JACK LONDON. (Diener)-Light salmon with orange flame stripes, golden yellow throat. (M., 3 for 10c)

J. T. PIRIE. (Kunderd) -Mahogany brown, cream throat marked brown, large blooms on straight tall spike. Attracts lots of attention. (L., each 5c) (M., 2 for $5 \mathrm{c}$ ) (S., 15c per doz.)

KIRCHOFF'S VIOLET. (Kirchoff)-Rich violet blue; good grower and multiplier; the best dark blue at the price and one of the two best at any price. (L., each 10c) (M., each $5 \mathrm{c}$ ) (S., 2 for $5 \mathrm{c}$ )

LASCINATUS. (Kunderd)-Rose pink, with edges of petals lascinated, or scalloped. Medium size bloom. A novelity. (L., each 5c) (Mi., 5 for $10 \mathrm{c}$ )

LEWIS DINGMAN. (Goodrich)-Another of C. L. Goodrich's new varieties; in color darker than rose ash and different shape; long spike with well placed large blooms with dark red blotch in throat. One of the best of the smoky novelties; midseason. (L., each 10c) (M., each 5c) (S., 2 for $5 c$ ) 
LONGFELLOW (Decorah)-Tall; La France pink; many blooms open; flowers large, wide open. One of the best of the new varieties; very much in demand; early midseason. (L., each 6c) (M., 2 for 5c) (S., 6 for 10c)

LOS ANGELES. (Houdyshel) -Delicate pink with cerise feather in the throat; called the cut and come again gladiolus. Sometimes it has side shoots which come out from the main stem very low down, below the usual place of cutting. In great demand; heavy propagator; midseason. (L., each 5c) (M., 2 for 5c) (S., 15e per doz.)

LUSTRE. (Kunderd) - Tall large flowered orange • vermiliion, a grand and beautiful dark red varieety, well liked by everyone who has grown it. (L., each 8c) (M., 3 for 10c) (S., 6 for 10c)

MADAM MOUNET SULLY. (Lemoine)-One of the best French originations; large blooms, perfectly placed, many open; milky white with bright orange red blotch in threat, very attractive early midseason. (M., ea. 10c) (S., єa. 5c)

MABEL IRVING. (Briggs)-Large deep pink ruffled wide open flowers; tall strong plant; midseason. (L., each 15c) (H., each 8c) (S., 3 for 10c)

MASTERPIECE. (Kunderd) - A magnificent ruffled "American Beauty" rose color, griant flower and plant. (M., each 6c)

MERCED. Charmingly beautiful; one-fourth Pribulinus. A brilliant orange safiron in color shading into a lighter yellow in the throat. The bloom is large, ruffled, well opencd and only slightly hooded. Good grower and multiplier. (L., each 5c) (M., 2 for $5 \mathrm{c}$ ) (15c doz.) 
MINUET. (Coleman) - A very beautiful shade of delicate clcar lilac lavencer; four to six open. large flowers. Strong, sturdy grower and a good progagator. Finest lavender ever produced. It is the standard by which all lavenders are measured. (L., each 25i) (MI., each 15c)

MISEION BELLS. (Briggs)-One of the loveliest and most distinct of the newer glads. Five to seven large round bell-shapcd blossoms of rich crange pink open at one time and are placed ail facing one way on tall straight willowy spike. (L., each 8c) (M., 3 for 10s) (S., 6 for 10s)

MRS. C. M. VOSBURG. (Goodrich)-Winner first prize Iowa State Pair for the past three years in medium pink class. Large blooms grenadine pink shading to darker tips, lower petals pale safirno pink with feather of scariet; midseason. (L., each 15c) (S., each 5c)

IIPS. F. C. HORNBERGER. (Hornberger)Large white with no mariking; several open; a nize winner at the big shows. This is considered che of the very best white varieties; late. (M., (ach 10e)

MPS. F. C. PETERS. (Fischer)-A beautiful shade of rose lavender with soft crimson bloteh; fiotyers splendid form, many open, tall straight apikc. One of the best; midseason. (L., each fc) (M., 3 for 10c)

DTES. FRANK PENDLETON. (Kunderd)-Bright rose pink; giant blotch of carmine red on lower petals. One of the best varieties ever introduesd; midseason. (L., 3 for 10c) (M., 6 for 10c) iᄂ., o. per doz.) 
MRS. LEON DOUGLAS. (Denier)-Salmon rose pink, striped with flame and scarlet, one of the tallest, largest and showiest gladiolus in existence; several immense blooms open at once. (L., each 6c) (M., 2 for 5c) (S., 15c per doz.)

MARIE KUNDERD. (Kunderd) - The finest early white gladiolus in the world; large blooms 5 t? $5 \frac{1}{2}$ in., rufled; snow white with faint pink lines in the throat; pointed petals; good substance; often has one or more side spikes; early. (L., cach 5c) (M., 2 for 5c) (S., 15e per doz.)

IIARSHAI, FOCH. (Kunderd)-Tall spikes bearing lange, ruffled flowers of wam salmon pink, the salmon tine being more vwoulounced towark the edre of the petals; wide open flowers; midseacon. (L., each 10c) (M., each 5c)

MYRA. (Kunderd)-Showy giant flowered PrimHybrid. Yellow with a salmon sufrusion; throat yellow with pink lines, tail, graceful, slender stems. (L., each 5c) (M., 2 for 5 c) (S., 10c doz.)

NANCY HANKS. (Salbach) - Peach red to orange pink, large weli spaced blooms on strong erect spikes. Fine for landscape planting; stays in bloom a long time. Side spikes produced freely. Stands dry, hot weather remariably well. (M., 3 for 10c) (S., 3 for $5 c$ )

OLIVE GOODRICH. (Goodrich)-White, tips of patals edged deep pink; inner throat tinted yellow; won first prize for me at lowa State Fair, for best light pink; midseason. (L., each 10c) M., each 5c) (S., 2 for $5 c$ ) 
OPALESCENT. (Purple)-Pale lavender tinted rose with darker lines in throat; nice easy grower; a good commercial variety; early midseason. ( $1 .$, each $5 \mathrm{c}$ ) (M., 2 for $5 \mathrm{c}$ ) (S., 4 for $5 \mathrm{c}$ )

ORANGE FLAME. (Kunderdi)-Orange scarlet, shading lighter toward upper center. Small velvely purpish spot on fiame orarge lip. Heavily suffled, very beautiful. Late. (L., each 10c) (M., each 5c)

OMANGE QUEEN. (Pfitzer)-Fine orange yellow; deeper at edge of petals; orange red lines in throat; tall; five to seven blooms open; a beautiful variety and a prize vinner; midseason. (L., each 5 c) (M., 2 for $5 \mathrm{c}$ ) (S., 4 for $5 \mathrm{c}$ )

PARAMOUNT. (Kunderd)-A wonderful blend-ing of sea shell pink and cream. An exquisitely delivate colored variety. (L., each 10c)

PFITZER'S TRIUMPH. (Pfitzer)-Immense sixinch blocms of orange red with a velvety red bloten in the center; one of the largest, showiest glads grown. (Mi., each 15e)

PINK CLOUD. (Kunderd)-Large, showy, ruffled variety; many sofit rose pink blossoms open at a time; bcautiful deeper rose throat; medium early. (L., each 8c) (MI., 2 for 5c) (S., 15c doz.)

PRIDE OF WANAKAH. (Criswell) - Large blooms of rich lavender-rose shading to a deeper rose in the throat, tall spike, strikingly showy. Midccason. (M., each 5c) (S., 3 for $5 c$ ) 
PURPLE GLORY. (Kunderd)-Very tall, strong growing plant with massive, deep velvety maroon flowers with almost black blotch; heavily ruffled. First prize, Iowa State Fair, for best variety Kunderd originations; midseason. (L., each 5c) (M., 2 for 5c) (S., 6 for 10c)

PURPLE QUEEN. (Kunderd)—Deep violet purple self-colored variety. Several large, well placed ruffled blooms open. First prize Iowa Glad Society Show, for best purple variety. (L., each 8c) (M., 3 for 10c) (S., 6 for 10c)

QUEEN OF ORANGE. (Kunderd)-Very large orange red, blooms 5 inches across, tall stately plant, an extra showy landscape variety. (M., each $5 c$ ) (S., 2 for $5 c$ )

RAJAH. (Kunderd)-Very choice giant dark red self-colored. The best in this color. (M., each $5 \mathrm{c}$ ) (S., 2 for $5 \mathrm{c}$ )

RED FIRE. (Kunderd)-Rich, pure self-colored bright red, very striking and showy; tall and considered the best bright red. (M., each 5c)

REFLECTION. (Goordich) -A beautiful flower, pure white, large petals blotched fiery scarlet, center of upper petals tinted rosy pink as reflecting the lower blotch; tall spike. (L., each 6c) M., 2 for $5 c$ ) (S., 15e per doz.)

RICHARD DIENER. (Diener) - Large geranium pink, or rose salmon; creamy yellow throat speckled ruby; nearly whole spike open at once; one of the most beautiful gladiolus in existence. A prize winner; midseason. (L., each $5 \mathrm{c}$ ) (M., 2 for $5 \mathrm{c}$ ) (S., 15c per doz.) 
ROSE ASH. (Diener)-A pastel shade; ashes of roses; large blooms; odd but pretty; very tall, strong grower. A popular variety; midseason. (L., each 4c) (M., 6 for 10c) (S., 15c per doz.)

ROSE GLORY. (Kunderd) - Light rose pink, large blooms, wide open, ruffled, a favorite florists' variety. (M., 2 for $5 \mathrm{c}$ )

ROSEMARY. (Bales)-An unusual new variety; with fine hair lines of lavender tinted rose; adorable in its delicate coloring. The marking $\mathbf{s}$ are carried clear through the petals; midseason. (L., each 5c) (M., 2 for 5c) (S., 15c per doz.)

ROSE MIST. (Fischer)-Primulinus grandiflorus variety in a class by itself; old rose with buff showing through. Fine buff lines on edge of petals. Five or more well placed blooms open on tall, straight spike. (L., each 8c) (M., each 5c) (S., 3 for $5 c$ )

RUFF'LED GOLD. (Goodrich) - Beautifully and heavily ruffled yellow with rose pink feather in throat. Six or more perfectly placed blooms open. Slender, stiff stem. An artistic, beautiful yellow that is different from other yellows. (M., each 15c)

RUFFOLACE. (Kemp)-White, nicely ruffled and ginely lascinated or fringed. The flowers average four inches or more in diameter and are borne on tall, stout stems. (L., each 20c) (M., each $10 \mathrm{c}$ ) (S., each $5 \mathrm{c}$ ) 
SALMON GLOW. (Hornberger) - Primulinus grandiflorus type; very large clear salmon; five inches or more across; clear yellow lip. First to bloom for me the past two seasons; early. (L., each $5 \mathrm{c}$ ) (M., 2 for $5 \mathrm{c}$ ) (S., 4 for $5 \mathrm{c}$ )

SARABAND. (Salbach) - Very large, wide open blossoms of rich velvety bordeaux with strawyellow blotch; tall spike, perfect placement, excellent substance; best of the smoky varieties. (M., each 10c) (S., each 5c)

SCARLANO. (Kunderd)-Tall ruffled scarlet red, straight spike. A fine commercial variety. Medium early. (L., each 5c) (M., 2 for 5 c)

SCARLET PRINCEPS. (Kunderd)-Plain petaled; pure scarlet; throat a little deeper; large blooms; lasts extraordinary well as a cut flower; midseason. (M., 3 for $10 \mathrm{c}$ )

SCARLET WONDER. (Cowee)-Glowing, brilliant velvety, pure scarlet. Several large blooms open at one time and perfectly placed on tall, strong stems. (L., each 5c) (M., 2 for 5c) (S., 15c per doz.)

SMOKY. Originated by Diener, introduced by Hutt. Smoky copper bronze, a beautiful, unusual color, fades in the sun; should be cut when first blooms open; large blooms. Identical with the variety SECAJAWEA (Pratt). (L., each 10c) (M., each $5 \mathrm{c}$ ) (S., 2 for $5 \mathrm{c}$ ) 
SOVEREIGN. (Vaughn)-Purple blue; tall plant and spike; color similar to Baron Hulot. Blooms from small bulbs and bulblets. (L., each 6c) (M., 2 for $5 \mathrm{c}$ ) (S., 4 for $5 \mathrm{c}$ )

SPLENDORA. (Kunderd)-Dark maroon; one of the best of the dark colored gladiolus; stands the heat better than any of the dark varieties; midseason. (M., 3 for $10 \mathrm{c}$ )

ST. THOMAS. (Kunderd)--Large salmon rose tinted with scarlet with a deep purplish black blotch. The showiest of all blotched varieties. Attracts lots of attention in the garden. (L., each 8c) (M., 3 for 10c) (S., 3 for $5 c$ )

SWEET ROSE. (Kunderd)-Pure rose with deeper colored feather in the throat. Large blooms on a tall, straight spike. An extra fine rose variety. (L., each $10 \mathrm{c}$ ) (M., each $5 \mathrm{c}$ ) (S., 2 for 5 c)

TYCKO ZANG. (Austin)-Immense salmon pink, white throat faintly dotter cerise, very large heavy foliage. Tall, strong grower and a good progagator. (M., 2 for $5 \mathrm{c}$ ) (S., 4 for $5 \mathrm{c}$ ) 
TYRIAN BEAUTY. (Kunderd)-Dark American Beauty or Tyrian Rose color. Several large blooms open; one of the tallest of all glads; very popular. (L., each 5c) (M., 2 for $5 c$ )

ULYSSES. (Kunderd)-Large, round flower. Smoky blue on rose-pink ground, deeper throat; very attractive. (M., each $5 \mathrm{c}$ )

VIELCHENBLAU. (Pfitzer)—Tall, large, dark violet blue; the finest dark blue on the market; one of the best foreign varieties; midseason. (L., each 25c)

W. H. PHIPPS (Diener)-Pale LaFrance pink overlaid light salmon rose; 10 to 15 large blooms open at once from a large bulb; extra fine; late. (L., each 6c) (M., each 3c) (S., 6 for 10c)

WM. G. BADGER. (Metzner)-Very large light salmon rose; throat cream specked with ruby; fine variety; midseason. (L., each 5c) (M., 2 for 5c) (S., 4 for $5 c$ )

VAUGHN'S WHITE. (Vaughn)—Large bloom, plain petaled, tall spike; a fine white; strong grower. (L., each 10c) 



\section{ORDER BLANK}

\section{Date.... ..........193...}

\section{Name}

\section{Address}

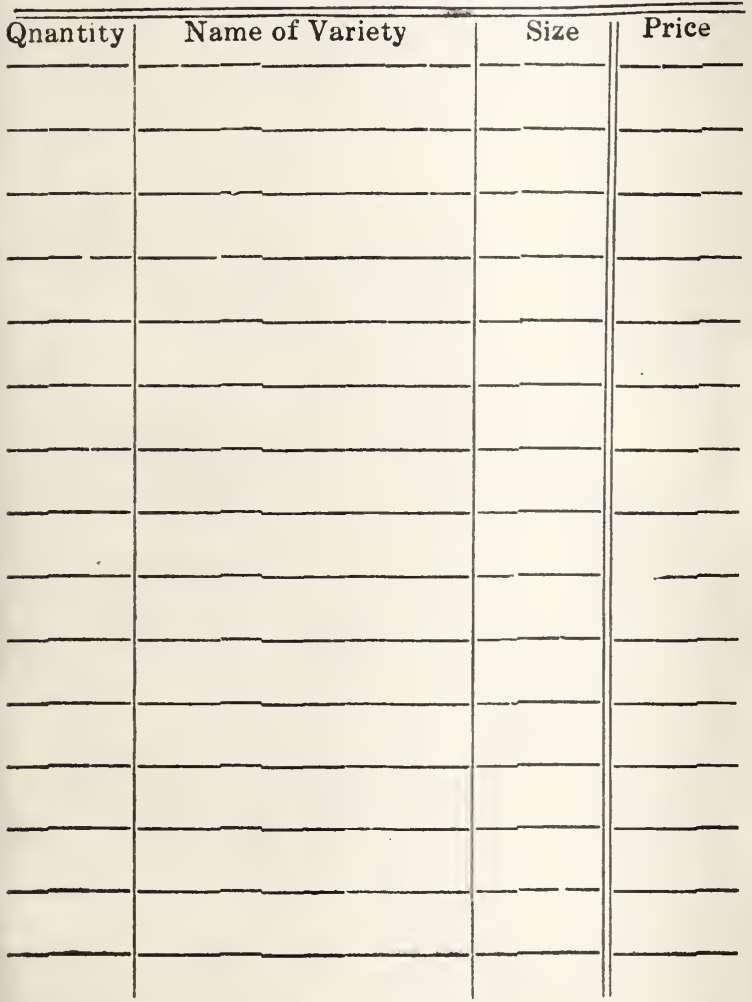


